\title{
Comparison of Nurcholis Madjid and A. Hasyim Muzadi's Thoughts on Renewal in Indonesia
}

\author{
Aam Saepul Alam', Rafiudin'2, Adang Sonjaya ${ }^{3}$ \\ ${ }^{1}$ STAI Siliwangi, Garut \\ 2 Sekolah Tinggi Ilmu Komputer Cilegon \\ ${ }^{3}$ STAI April, Sumedang \\ *Corresponding author E-mail: aamrs2017@gmail.com
}

\begin{abstract}
This study aims to understand the differences and similarities in the thinking of two figures from different organizations. Two different thinkers and reformers of educational and organizational genealogy, namely Nurcholis Madjid and Hasyim Muzadi. Nurcholis Madjid (Cak Nur) graduated from Western education, and Hasyim Muzadi graduated from a local boarding school education. The method used in this study, using a qualitative approach with a Comprehensive Study approach and through the Hermeneutic approach. Observing the results of the study provides insight into Nurcholis Madjid and A. Hasyim Muzadi, having differences in their ideas. Nurcholis Madjid gave birth to Universal Islamic ideas, and Hasyim Muzadi gave birth to rahmatan lil alamin in religious contexts. The similarity of the two figures is to promote Islam that is full of peace, harmony, and harmony.
\end{abstract}

Keywords: A. Hasyim Muzadi, Islamic thought, Nurcholis Madjid

\section{INTRODUCTION}

Movements and thoughts of religious renewal have always been an essential part of Islamic tradition throughout its developmental history. The pioneers of reform were present to renovate the beliefs, knowledge, and religious practices of the Muslim community. Even though the orthodox did not recognize the presence of prophetic figures after the Prophet Muhammad, the majority of the Muslim community believed that in each episode of history and different regions of the Islamic world, reformers appeared to oppose the status quo and initiate a change. Some research studies on Hasyim Muzadi, including Islam Rahmatan Lil Alamin Perspective Kh. Hasyim Muzadi, and the Nurcholish Madjid Inclusive Theology: Harmonization between Islam, Indonesians, and Modernity by Z. Abiddin. For example, in the 17-19th century AD, several figures and reform movements emerged in the Islamic world, which, based on the setting of the emergence and orientation of the action, could be divided into three episodes. First, Shah Waliullah in India, Ahmad bin Abdul Wahhab in Saudi Arabia, and Muhammad bin Ali al-Sanusi in North Africa. During this time, leaders and reform movements emerged concerning internal pressures or the environment (Khalid Masud et al., 2009) and were slightly in touch with the impact of the development of Western civilization. Their presence is in the context of opposing the practice of taqlid (blind imitation) and fanaticism of the school (taqdis al afkar al diniy), because both of them are seen to have caused a rift in the Muslim community (Saeed, 2006). Secondly, as European colonial penetration into the Islamic world increased, several jihadi movements began in the 19th century, as a critical aspect of Islamic reform. For example, in response to British colonization in the Indian subcontinent, the scholars declared that India could no longer be called the "abode of Islam" (dar al-Islam), but as the "abode of war" (dar al harb). In the early 1800s, Haji Shariatullah declared that India was a war zone and called for jihad against the British colonies in Bengal. Likewise in West Africa, Sheikh Usman bin Fudi(w. 1817), better known as Shehu

* Copyright (c) 2020 Aam Saepul Alam et.all

This work is licensed under a Creative Commons Attribution-ShareAlike 4.0 International License.

Received: May 05, 2020; Revised: July 21, 2020; Accepted: July 26, 2020 
International Journal of Islamic Khazanah, Vol. 10 No. 1: 1-10

Comparison of Nurcholis Madjid and A. Hasyim Muzadi's Thoughts on Renewal in Indonesia

Aam Saepul Alam, Rafiudin Rafiudin, Adang Sonjaya

Usman and Fodio, along with his daughter (a well-known literary and educator) Nana Asmau (w. 1864), had succeeded in starting jihad and establishing the Caliphate of Sokoto, the most massive Islamic power in Africa in the 19th century. Two illustrations of this aspect of reform in the military field are essential, as a view, which also forms a significant part of understanding the anti-colonialism agenda of Muslim society in the 20th century. Third, along with the arrival of the modern era (19th century and beyond), the tradition of religious renewal continues more intensively than in the previous period. At that time, the military and political confrontation of Western powers with the Islamic world was announced, and the Muslim community suffered defeat (Boyd, 2001). The modernism of Muslim societies that occurred in this era was partly a continuation of the 18-19M century reform movement, and some others were a way of responding to the challenges presented by Western modernity when there remained a fistful of faith in religious grounds.

Some Muslim reformers who tried to answer the challenges of Western modernity, for example, Jamaluddin al Afghan (1897), Muhammad Abduh (1905) in the Arab world, Sayyid Ahmad Khan (1898) and Muhammad Iqbal (1938) in India, and some thinkers from the Ottoman Turks, like Namik Kemal (1888). In this section, reform or renewal is a central theme (key theme) for modernists. Jamaluddin alAfghani, for example, argued that Muslim societies must carry out reform movements as European Christian communities played this critical role.

Some previous research studies on Hasyim Muzadi, including Islam Rahmatan Lil Alamin Perspective Kh. Hasyim Muzadi, and the Nurcholish Madjid Inclusive Theology: Harmonization between Islam, Indonesians, and Modernity by Z. Abiddin. The modern context demands a re-appreciation of Muslim intellectual, cultural heritage, including the works of the first generation of scholars. Other critical ideas of modernists are a return to the pristine Islam of the earliest Muslim age (salaf), revitalization of Islamic intellectual traditions, interpretation or reinterpretation of cultures and their sources to answer the challenges posed by the modern era, so a new theological system is needed here(Khalid Masud et al., 2009). Here the author will explore about Indonesian thinking in the reform era, first the study of the figures representing it, namely Hasyim Muzadi (NU), as according to Ketut, Hasyim Muzadi's thoughts are full of letters and verses in building religious tolerance (Media Indonesia, 2017) and Noercholis Majid (Muhammadiyah), secondly, the study of fundamentalist and modernist organizational movements. Madjid is a phenomenon that is not only interesting, but also unique and confusing, both in the discourse of religious thought (Islam), culture, and politics in Indonesia (Abidin, 2014).

\section{METHODOLOGY}

The research is qualitative by using a comparative study method, carried out by comparing the similarities and differences between the two figures. This method is done by paying attention to the phenomena that influence the factors that gave birth to ideas and ideas from history (history) of the two thinkers. Collection of primary data from work and lectures. And the hermeneutic approach that will be used in this research is hermeneutic-grammatical, historical hermeneutic, and philosophical hermeneutics. The first serves to explore everything related to language so that it can interpret the text. Secondly, it functions to search for history, works, and authors, while the third, function as control of reasoning from the other two forms of interpretation. 


\section{DISCUSSION AND RESULTS}

\section{Reform of Islamic Reformation Era}

The renewal also uses the treasures of classical Islamic thought before, like Ibn's thought. Thaimiyah, Ibn. Qayyim, Abd.Wahhab and Abduh and others. Fazlur Rahman has divided Islamic reformation into several periods, beginning with the period of pre-modernist revivalism, classical modernism, neo-revivalism, and neo-modernism. The renewal of Islamic thought introduced in the 17-19 AD century can be found in Indonesia since the beginning of the 20th century through the presence of Muhammadiyah and Islamic Unity, which made purification or purification of the creed a central theme of their movement. Like the thoughts of the new Ahmad bin Abdul Wahhab and Muhammad Abduh, the early episodes of the history of Indonesian Islamic modernism were also marked by a passion for releasing orthodox ties. The things done are by promoting ijtihad rather than taqlid, emphasizing the importance of qiyas to seize the spirit of the law that is stored in legal writings, and choosing to reduce dependence on Hadith to prioritize the Qur'an and the Sunnah of the Prophet (Barton \& Tahqiq, 1999). The vision of modernity proposed by Muhammadiyah and Persis for nearly a decade and a half gave rise to tensions with conservative groups, consisting of pesantren Kiai. This traditional group of Kiai considers that ijtihad related to fundamental problems in law is impossible and not necessary. They argue that the classical scholars of the founders of the four schools have unparalleled expertise since the tenth century so that the truth in the field of Islamic law is unquestionable. It is for this reason that traditionalist ulama treat taqlid to the legal principles proposed by the school of Imams. This dispute, in turn, encouraged the Kiai to form a highly influential religious, social organization in Indonesia, the Nahdlatul Ulama (NU), which was founded in 1926 as the culmination of the conservative reaction to the Muhammadiyah modernist movement (Sutarto, 2005).

Until the second half of the 20th century, the modernism movement in Indonesia was marked by theological tension and even developed in a political direction between Muhammadiyah and NU, so as happened in the other Islamic world, the Indonesian Islamic reform movement eventually also took a relatively stable style in the field of politics. Even though the tension of Muhammadiyah and NU is not a full reflection of the anti-Western attitude. Modernization in Indonesia has similarities with postrevolutionary Iran, where intellectuals are polarized into two spectrums, namely those who agree on the narrative of Western modernity with the religious perceptions of anti-Western societies. Seeing these conditions, Michel Foucault asked a slightly sarcastic question, "what exactly is happening in Iran (and Indonesia, pen.), Where most people, who are on the left or right bow, look a bit irritated?"(Foucault, 1988).

\section{Study of Thought Reform of Thought in the New Order era by Nurcholis Majid}

A representative of reformers of New Order thinking, Nurcholis Madjid, a Doctor from Chicago University, has pioneered the reform movement since the 1970s. The renewal milestone began when he expressed his thoughts in a halal bi halal lecture in Jakarta on January 3, 1970. In the event attended by Masyumi, HMI, PII, and GPI successors activists, Nurcholish delivered his paper entitled "The Need for Renewal of Islamic Thought and The problem of integration of the people. "In this horrendous paper, he offers the secularization and liberalization of Islamic thought (Foucault, 1988).

Since launching his secular ideas in the 1970s as an intellectual, Nurcholish thought has been studied and discussed in the context and dynamics of islamic and indonesian. He was even dubbed as the "lokomotif kaum pembaharuan (renewal locomotive)" who was incorporated into the Islamic neo- 
International Journal of Islamic Khazanah, Vol. 10 No. 1: 1-10

Comparison of Nurcholis Madjid and A. Hasyim Muzadi's Thoughts on Renewal in Indonesia

Aam Saepul Alam, Rafiudin Rafiudin, Adang Sonjaya

modernist school along with Harun Nasution, Abdurrahman Wahid, Jalaluddin Rahmat, and others (Urbaningrum, 2000). It is different from the paradigm of modernists and traditionalists (Al Qurtuby, 2017). Neo-modernism thought is a school that seeks to combine the authority of revelation with dynamic social reality. Between transcendent revelation and profane context. Therefore, Nurcholish tried to build a vision of Islam in modern times, by not leaving Islamic intellectual heritage at all. Even if possible, look for the roots of Islam to get Islamic modernity itself (Rakhmat \& A.K, 2003).

Since its inception in the 1970s, Nurcholish was transformed into a phenomenon as well as a controversial figure, and his thoughts were greatly appreciated and resistant, especially his concept of inclusivism that emerged in the midst of the mainstream of exclusivism. If categorized simply, there are three views and tendencies of the community in responding to Nurcholish thoughts and figures. First, a favorable light - empathic who positions it as a dialogue partner for the same theological anxieties. The implication is that all Nurcholish thought is accepted without reserve, without being critical. In this context, Nurcholish thoughts produce a significant transformation process, especially in encouraging changes in aspects of thinking and religious attitudes. They are a group of young Islamic thinkers. For this group, Nurcholish is a reformer figure who is worthy of respect, and his snowball thoughts must continue to be rolled. Second, the critical view, which places Nurcholish and his thoughts outside the mainstream frame of Muslim thought. The implication is apology and resistance to Nurcholish thought. Strong reaction and even theological sentences embedded in it, such as heresy. Third, it is the view of sympathy that places Nurcholish and his thoughts objectively and independently. This group sees that there are many positive aspects and benefits of Nurcholish's ideas, but also being critical and objective that there are weaknesses (Aba Du, 2004).

Theoretical Framework of Nurcholish Madjid The conceptual framework of all Nurcholish thought is built from a fundamental question, which is how universal Islam can be placed within the context of modernity and local culture. Islam is global, and the implication of its universality is that Islam must be understood and implemented in every space and time. Thus Islam can even have to be adapted to modernity. If there is a conflict between Islamic teachings and the achievement of modernity, then what must be done is not to reject the modernity but to reinterpret the teaching (Madjid, 1992). Authenticity and modernity cannot be released in response to the problems of the people. In other words, an awareness of the richness of tradition and the ability to continually innovate in Indonesian "space" and "time" in modern times are needed.

In reconstructing his thoughts, including his inclusive theology, Nurcholish uses a criticaldeconstructive approach and a humanistic/anthropocentric approach (Suprayogo, 2001).

1. The critical-deconstructive approach, in contrast to classical thought, in Nurcholish's view, absolutism must be undermined, and relativism must be affirmed. Understanding what is considered truth by Muslims, in Nurcholish's opinion, the fact is not taken for granted, static, and unchanging. Every understanding of the truth is a continuous search process. Hence it is not single and not final. Knowledge of the truth is strongly influenced by the context of space and time. Therefore it is not absolute and really gives room for criticism. With such assumptions, it is not surprising that his thoughts are filled with new interpretations, critiques, revisions, and even deconstruction of Islamic concepts that have so far been considered final truths. The ultimate goal is to find new meanings that are fresher and progressive.

2. Humanistic-Anthropocentric Approach. In discovering his ideas, Nurcholish always used a humanistic approach, meaning that the defense of humanity was emphasized more than supernatural claims. Religion ultimately must defend humankind rather than the assertion of 
International Journal of Islamic Khazanah, Vol. 10 No. 1: 1-10

Comparison of Nurcholis Madjid and A. Hasyim Muzadi's Thoughts on Renewal in Indonesia

Aam Saepul Alam, Rafiudin Rafiudin, Adang Sonjaya

divinity. This humanistic approach in Nurcholish's view makes religion more down to earth, dialogue with the context of space and time. In other languages, ethnocentrism must be combined with anthropocentrism. Humans find their personalities intact only if they focus their original orientation on God. This transcendent concentration must be within the framework of anthropocentrism. To defend humanity, it must be clearly and precisely mapped into the worldly territory, which must be secularized and profiled and what constitutes religious territory, which is sacred and absolute. In Nurcholish's view, humanity is universal, so humans are equal without distinguishing between differences in attributes and religion. This humanistic approach is in line with the efforts of human benefit because faith must be for the benefit of humans, not for religion itself.

\section{Renewal of Thought after the Reformation era by KH Hasyim Muzadi}

In addition to studying at public schools, little Hasyim Muzadi also learns the Koran from his parents. He began his education at Madrasah Ibtidaiyah Salafiyah (elementary school level) Bangialan from grade one to grade three. The rest is completed at the People's school. Hasyim Muzadi had a chance to study junior high school education but did not graduate. At SMPN I Tuban for only 1.5 years, he moved to Gontor to continue his studies(Hasan, 2018). Hasyim Muzadi was the second person in Bangilan to study at Gontor. Previously, Hasyim's cousin had already departed. The difference is, Kiai Hasyim studied at Gontor until graduation, namely from 1956 to 1962. While his cousin dropped out in the middle of the road. Besides studying at Gontor, Kiai Hasyim had studied the Senior Islamic Boarding School, in Tuban, Lasem Islamic Boarding School, Central Java.

NU's first thought (fikrah) prioritizes moderate attitudes that have been grounded in the land of the archipelago. This is the hallmark of $\mathrm{NU}$ as the largest Islamic organization that has social, cultural values that can be accepted by the strata of society, except those who disagree with the ideas and movements NU in Indonesia. NU through the role of the Kiai and ulama in liberating the nation and reconciling by maintaining religious harmony and national harmony.

The journey of the Kiai always avoids radical attitudes, because that attitude is the least favored which will cause long-term adverse risks and away from the values of the benefit of the people, especially the unitary state of the Republic of Indonesia. The NU scholars prioritize the importance of moderation in dealing with problems, both religious and national issues by implementing factual and realistic principles.

Through the use of this aspect of al-tawassuth in the context of the nation and state, NU was able to sail between the rocks of extremism and liberalism, both words that were suspected as the cause of the destruction of a civilization. Extremism, which is characterized by opinion absolutism, acute fanaticism, and takfir-ism, often causes sectarian conflicts and ideological clashes. Liberalism, on the other hand, is suspected of influencing mindset in social, theological, and economic aspects. In the social field, liberalism is more likely to be interpreted as lifestyle liberalization, westernization, and modernization. In the area of theology, instead of provoking liberation, as the word liberal means, liberalism actually dwells on elitist discourses, is busy emptying qath'i doctrine, and is far from the meaning of freedom of the oppressed (mustadh'afin) and is suspected of being a continuation bourgeois-capitalist side. In the economic field, and this is the most influential, liberalism is more a rubber stamp policy in favor of the neo-liberalism (Zionis, 2016).

This Tawassuthiyah Fikrah also contains another keyword that is no less important, namely altawazun. In this paper, the word al-tawazun is interpreted as harmony. This keyword will be realized if there are various elements that are related to understanding the same. In the context of nationalism, the form of 
International Journal of Islamic Khazanah, Vol. 10 No. 1: 1-10

Comparison of Nurcholis Madjid and A. Hasyim Muzadi's Thoughts on Renewal in Indonesia

Aam Saepul Alam, Rafiudin Rafiudin, Adang Sonjaya

al-tawazun is that $\mathrm{NU}$ always strives to maintain pluralistic harmony, harmony among religious communities and, at the same time, gives various siyasi decisions that avoid the disintegration of Indonesia. NU's contribution since 1926 until now in various important events is the manifestation of harmony in the life of the nation and state. This bias can be seen clearly in the Jihad Resolution, awarding the title of waliyyul amri al-dharuri bi al-syaakah, defending the Republic of Indonesia from undermining the PKI, accepting the sole principle of Pancasila until the decision of the Republic of Indonesia is final.

In the context of this understanding, it is new sentences that have been delivered by KH. A. Wahid Hasyim follows:

"I say so (the excitement of the establishment of PTAIN-Pena) asking because I am a Muslim who is of Indonesian nationality, but as an Indonesian Muslim son" (Aboebakar, 1957).

The role of the NU Kiai continues to be passed on by the next generation, especially KH Abdurahman Wahid (GusDur) son of KH. Wahid Hasyim. In the role of GusDur against the Ambon Conflict in Maluku since 1999 is one example of this nation's wounds. When he became president, KH. Abdurrahman Wahid or Gus Dur devoted his life to the Indonesian people. In resolving this Ambon conflict, Abdurrahman used the paradigm of ukhuwah wathaniyah, namely the principle of brotherhood, because it has the same homeland, namely Indonesia. If Abdurrahman was utilizing the model of ukhuwah Islamiyah, then as a Muslim leader and as a Muslim president, Abdurrahman might have sent thousands of Bansers to conduct jihad there to help the Muslims. But Abdurrahman did not do it. When resolving the conflict, Abdurrahman did not choose to function as a "Muslim politician" who could ride the Ambon conflict issue for his political interests. Gus Dur precisely decided to become a true statesman, trying to reconcile the children of the nation torn by civil war, reconcile and realize that conflict will not produce benefits, because as the saying goes, win becomes charcoal, lose ash.

Although peace in Ambon occurred after Abdurrahman was ousted, the reconciliation efforts carried out since his time had sweet results. During the burning conflict, Abdurrahman secretly sent Minister of Religion KH. Tolchah Hasan and PBNU General Chairman KH. Hasyim Muzadi to become one of Ambon's peace mediators. NU was chosen to be the initiator of peace because, during this time, its attitude did indeed indicate religious moderates and its big vision of Indonesian Islam. Some hardline Christian leaders also see the sincerity and objectivity of $\mathrm{NU}$ in the peace process, so that the reconciliation process can be done quickly and accurately.

Nahdatul Ulama (NU), since its birth in 1926, gave birth to endless figures and great leaders. Not only the national level but also international. They have been proven to provide color to the life of the nation and state. One such figure is KH Hasyim Muzadi.

Generally, NU leaders, especially at the central level, were born from Kiai families with big names. But that is not the case with the man who is an activist of NU in East Java, familiarly called Kiai Hasim, "cak," which is East Javanese, which means brother. He was born from an ordinary family in Bangilan, Tuban, East Java, his father, Muzadi, a tobacco trader.

Many people were shocked when the majority of NU's 30th Congress participants in Lirboyo, Kediri, in 2000, decided to elect Kiai Hasim Muzadi as Chairman of the NU Grand Management. Kiai Hasyim was elected as chairman of the PBNU, who at that time was still the Chairperson of the West Java NU Regional Board, in the second period. He replaces KH. Abdurahman Wahid alias Gus Dur who led NU for three periods: 1984-1989,1989-1994, and 1994-1999. The conference was a historical moment in which village leaders rose to become NU's supreme leaders. Abdurrahman played a significant role in the election of Kiai Hasyim, because he, who was then the president, fully supported Kiai Hasyim. But after five years had 
International Journal of Islamic Khazanah, Vol. 10 No. 1: 1-10

Comparison of Nurcholis Madjid and A. Hasyim Muzadi's Thoughts on Renewal in Indonesia

Aam Saepul Alam, Rafiudin Rafiudin, Adang Sonjaya

passed, Gus Dur and Kiai Hasyim were in a position to face the NU's 31st conference in Donohudan Boyolali, Central Java, in 2004 (Hasan, 2018).

At that time, Gus Dur wanted to lead NU again. Whereas Kiai Hasyim, who remained hand in hand with KH. M. Ahmad Sahal Mahfudz, as Rais Am, intends to continue his struggle. At the heated conference, Kiai Hasim was re-elected as the Chairperson of NU. During the nomination stage, Kiai Hasyim received 293 votes, KH. Masdar F. Mas'udi 103 votes, KH. Mustofa Bisri 35 votes, Abdul Aziz 4 votes. Whereas Gus Dur and KH. Tholchah Hasan only got one vote. Then the selection of the next stage between KH. Masdar F. Masudi and KH. Hasyim Muzadi, at this stage, Kiai Hasyim, outperformed KH. Masdar F. Mas'udi with a vote ratio of 334 and 99.

The idea of Islam Rahmatan Lil Alamin which is used as an umbrella in da'wah, certainly has a significant difference in the order of practice with other beliefs, such as Liberal Islam and Pluralist Islam, Progressive Islam, Archipelago Islam, Kalap Islam \& Karib Islam, Developing Islam, and so forth. Everything will lead to the religion of mercy for the universe. However, both have a vision to read Islam with full tenderness, peace and be a solution for the world.

Hasyim Muzadi's ideas about Islam rahmatan lil alamin shows the difference with typical Liberal Islam, Transformative Islam, Progressive Islam, and progressive Islam (Rasyid, 2016). Islam that is understood by Hasyim gave birth to the idea of a peaceful Islam full of harmony both internally and externally. He actualized Islam in the context of harmonious religious and state relations.

Reactualization of rahmatan lil alamin in the thoughts and movements of Hasyim Muzadi during his leadership or after his administration, he more existed in the field of world peace and interfaith harmony. Reactualization of rahmatan lil alamin in the thoughts and movements of Hasyim Muzadi during his leadership or after his leadership, he more existed in the field of world peace and interfaith harmony. Therefore, it takes three beliefs originating from Abraham's ideas to make safety or peace the core of his teachings. For example, Islam means the total surrender of the will of God and unity among human beings by doing good deeds, for Jews, on the understanding of organic harmony, fulfillment of obligations, fulfillment of duties, kindness, or rationalization of various conflicts.

Dadang Kahmad stressed that understanding did not include the word "peace" in Western religious knowledge, which meant interpretation of conflict or passive acquisition by avoiding worldly affairs. Peace embodies, not only eliminating mutual suspicion, mutual harm, conquest, or war, but also creating the natural order of things (H. Kahmad, 2011).

The conflict in various regions never ended; this needs a severe solution for all components of the nation, including religious leaders. This, the Kyai Hasyim is very intense in reaching the terrorist movement in Indonesia, which continues to occur by bombing the area, especially in the police offices that became his target.

Hasyim Muzadi never agreed with the actions of the Police handler against terrorists, especially as did the Special Detachment (Densus) 88, which often shot dead suspected terrorists. Because, he said, such methods are the same as combating terrorism with a new terror.

The handling of terrorism, according to Hasyim Muzadi, must still be carried out in the legal consolidation. "Don't just shoot someone who hasn't been proven as a terrorist in court. It's called handling terrorists with terror". He also disagrees with the exposure of raids and arrests of suspected terrorists via live television (TV). That method fosters the resentment of relatives or sympathizers of the terrorists.

Logically, they can see how their relatives, fathers, brothers, or friends suspected of being terrorists were treated inhumanely by the authorities. In his view, Indonesia has successfully handled the case of terrorism elegantly and was able to be appreciated by many, including foreign countries, namely when 
International Journal of Islamic Khazanah, Vol. 10 No. 1: 1-10

Comparison of Nurcholis Madjid and A. Hasyim Muzadi's Thoughts on Renewal in Indonesia

Aam Saepul Alam, Rafiudin Rafiudin, Adang Sonjaya

handling the Bali bombing case with perpetrators, including Imam Samudra and Amrozi. At that time, the apparatus arrested the perpetrators alive, tried and sentenced, must be reapplied. Although in court, the perpetrators will be sentenced to death, such as the Bali Bombers, it is far better than shooting them dead without trial.

Kia Hasyim believes that terrorism is not the original character of the Indonesian people. Of course, some factors make terrorist groups born and thrive in the country. He analyzed, terrorism in the world can be categorized into two types, namely terror that is pure terror and terror that is part of the war. The terror that occurred in Indonesia, after the reformation era, was absolute terror because it happened in a peaceful country. Terror is part of the war, as is the case in Israel and Palestine.

He believes intellectual terrorist suicide bombing is an old terrorist group. Now, they have dared to attack and openly dare. The mosque was the target of the attack, as happened in the Polersta Mosque in Cirebon, West Java, June 15, 2011. That is an experimental proof that terrorism has nothing to do with the teachings of Islam and the teachings of Islam. Hasyim Muzadi said, strangely, all this time, there was labeling of Islam in acts of terrorism in Indonesia. This general labeling has led to many Muslims joining in. Then, omission occurs. If that attitude develops in society, terrorism in Indonesia will be permanently silent.

Kia Hasyim Muzadi considered that there was a permanent nation of terrorism in Indonesia to be a lifelong project. The proof is the response of the parties responsible for combating terrorism is more in the form of discussion, not in the way of acts of nayata deideolgisasi in the midst of society (Hasan, 2018).

Recognized or not, the handling of terrorism has so far been referring to the strength of the weapons of the police. Meanwhile, the role of civil society tends to be marginalized and ignored. The exclusion of civil society is counterproductive and does not target because it is unable to eradicate the roots of terrorists. The method used by Indonesia today is actually the same as the method used by the United States at the George W. Bush Mass Society, namely, pre-emptive action. That method failed, even bringing America into a wave of terror.

In Indonesia, this method has led to new terrorism. If it continues, the militancy of the terrorists will increase. As a result, they can be increasingly brutal to attack the police.

The United Nations (UN) issued a resolution stating the critical role of civil society groups in combating terrorism. However, the implementation of the decision is also still weak in Indonesia. The handling of terrorism needs to involve civil society groups because terrorism has many forms, and its manifestations can be in many ways. Civil society groups can help overcome terrorism from non-physical aspects, such as ideology and socio-economic conditions(Foucault, 1988).

As a modern mass organization, $\mathrm{NU}$ has given more attention to the problem of terrorism in Indonesia. On various occasions, NU actively campaigned for moderate Islam and anti-terrorism, in national and international forums. For NU, the strengthening of modern Islam can stem radical Islamic groups. Through the NU locomotive, Hasyim Muzadi conducted a campaign on Islam rahmatan Lil alamin continued without ceasing until he died.

It happens because of the awareness that the handling of terrorism is not only the responsibility of the government but also the responsibility of the community and religious organizations. In fact, the issue of terrorism has become a special discussion at the 32nd NU conference, in Makassar, South Sulawesi, 2010. The Conference Recommendation emphasized the importance of civil society participation in combating terrorism.

Learning from Indonesia's experience of failing to counter-terrorism, in Kiai Hasyim's view, there are several aspects of the approach that must be taken: 
International Journal of Islamic Khazanah, Vol. 10 No. 1: 1-10

Comparison of Nurcholis Madjid and A. Hasyim Muzadi's Thoughts on Renewal in Indonesia

Aam Saepul Alam, Rafiudin Rafiudin, Adang Sonjaya

1. Ideological and religious elements. It requires the participation of social organizations, such as NU, Muahammadiyah, and interfaith. The pesantren Kiai, community leaders, and interreligious need to be moved simultaneously. Their task is to straighten out the wrong understanding of religion or deradicalize ideology to the broader community. Terrorism exists because of a misunderstanding of the nature of religious teachings. This misunderstanding then in 2006 has developed into misuse of religion. Because the root of terrorism is the wrong ideological understanding, the attention of the authorities must not only focus on the form of terror.

2. Legal aspects. To eradicate terrorism, enough laws are needed so that the authorities can move in the field with measurable steps. Do not let the apparatus precisely be considered to violate human rights. Moreover, the police are now not fully supported by opinions, broad community participation.

3. Intelligence approach and territorial approach. Because terrorists in Indonesia are moving underground, the handling of terrorism cannot be carried out on the ground. This is where an intelligent approach is needed. If the police are unable to move optimally, it should involve TNI intelligence. The two institutions must work together without negating each other.

4. Security and repression aspects. The duty of the state, especially the police, is to create a sense of security in society from the threat of terrorism. Therefore, handling all terrorism cases must be resolved. However, it should be noted, how violence can lead to new terrorism, so we need another approach.

5. Political will. In this case, the head of the state needs the task of taking a position in handling terrorism that continues to threaten. Only the head of state can move all elements of the Indonesian people in the framework of carrying out integrated handling of terrorism.

The end of all these aspects above is the legal process against terrorists. In the past, captured the lives of people suspected of terrorism.

\section{CONCLUSION}

Both reformers (Cak Nur and Kiai Muzadi), gave a special color to Indonesia. Cak Nur built how to realize Islam and Indonesia with an established theological approach, through two approaches in building Islamic thought as a renewal in Indonesia. First, a critical - deconstructive approach. This approach is different from classical thought, in Nurcholish's view, absolutism must be undermined, and relativism must be affirmed. Understanding that is considered truth by Muslims, in the sight of Nurcholish truth, is not taken for granted, static, and unchanging Humanistic-anthropocentric approach. Second, the Humanistic approach. In discovering his ideas, Nurcholish always used a humanistic approach, meaning that the defense of humanity was emphasized more than supernatural claims. Religion ultimately must defend humankind rather than the assertion of divinity. This humanistic approach in Nurcholish's view makes religion more down to earth, dialogue with the context of space and time. Likewise, Kiai Hasyim Muzadi gave Rahmatan lil an Islamic style of nature in reform in Indonesia as an Islamic moderation. Rahmatan Islam Lil Alamin was used as NU's jargon in implementing diversity in the national context. Kiai Hasyim Muzadi, as the icon of Gus Dur's leader, made Islam Moderation, realized on the international scene through ICIS. This research is only limited to the thoughts of the two figures. For this reason, the writer hopes that there will be other studies that discuss the implications for the context of Indonesian cities. 


\section{REFERENCES}

Aba Du, W. (2004). Ahmad Wahid: pergulatan doktrin dan realitas sosial (R. Hidayat (ed.)). Langit Aksara.

Abidin, Z. (2014). Teologi Inklusif Nurcholish Madjid: Harmonisasi Antara Keislaman, Keindonesiaan, dan Kemoderenan. Humaniora, 5(2), 665. https://doi.org/10.21512/humaniora.v5i2.3123

Aboebakar, A. (1957). Sedjarah Hidup KH. Abdul Wahid Hasjim dan Karangan Tersiar. Panitya Buku Peringatan Alm. K.H.A. Wahid Hasjim.

Al Qurtuby, S. (2017). Era Baru Fiqih Indonesia (M. Zainal Muwahib (ed.); 1st ed.). lembaga study sosial dan agama (el.sa)press.

Barton, G., \& Tahqiq, N. (1999). Gagasan Islam liberal di Indonesia : pemikiran neo modernisme, Nurcholish Madjid, Djoko Effendi, Ahmad Wahib dan Abdurrahman Wahid (E. A. Effendy (ed.)). Paramadina.

Boyd, J. (2001). Distance learning from purdah in nineteenth-century northern Nigeria: The work of Asma'u Fodiyo. Journal of African Cultural Studies, 14(1), 7-22. https://doi.org/10.1080/136968101750333941

Foucault, M. (1988). Politics, philosophy, culture: Interviews and other writings, 1977-1984. In L. D. Kritzman (Ed.), Politics, Philosophy, Culture: Interviews and Other Writings, 1977-1984. Routledge. https://doi.org/10.4324/9780203760031

H. Kahmad, D. (2011). Sosiologi Agama Potret Agama dalam Dinamika Konflik, Pluralisme dan Modernitas. Pustaka Setia.

Hasan, A. M. (2018). Biografi A. Hasyim Muzadi (M. Arief Hidayat (ed.); 1st ed.). Keira Publishing.

Khalid Masud, M., Salvatore, A., \& Van Bruinessen, M. (2009). Islamic modernism. In Islam and modernity: Key issues and debates (1st ed.). Edinburgh University Press. https://www.amazon.com/Islam-Modernity-Key-Issues-Debates/dp/0748637931

Madjid, N. (1992). Islam Doktrin dan Peradaban : Sebuah Telaah Kritis Tentang Masalah Keimanan, Kemanusiaan dan Kemodernan. Paramadina.

Media Indonesia. (2017). Pemikiran KH Hasyim Muzadi Patut Diteladani. Mediaindonesia.Com.

Rakhmat, J., \& A.K, S. (2003). Prof. Dr. Nurcholish madjid : jejak pemikiran dari pembaharu sampai guru bangsa (S. A.K. (ed.)). Pustaka Pelajar.

Rasyid, M. M. (2016). Islam Rahmatan Lil Alamin Perspektif Kh. Hasyim Muzadi. Epistemé: Jurnal Pengembangan Ilmu Keislaman, 11(1), 93-116. https://doi.org/10.21274/epis.2016.11.1.93-116

Saeed, A. (2006). Islamic thought: An introduction. Islamic Thought: An Introduction, 1-204. https://doi.org/10.4324/9780203015247

Suprayogo, I. (2001). Metodologi Penelitian Sosial Agama. Remaja Rosda Karya.

Sutarto, A. (2005). Menjadi NU Menjadi Indonesia: Pemikiran K.H. Abdul Muchith Muzadi (2nd ed.). Khalista.

Urbaningrum, A. (2000). Islamo-Demokrasi : Pemikiran Nurcholish Madjid. Universitas Indonesia.

Zionis, R. M. (2016). Fikrah Nahdliyah Sebagai Pondasi Kehidupan Berbangsa Dan Bernegara. Jurnal $\begin{array}{lll}\text { Pikir, } & 2(1), & 1-19 .\end{array}$ http://ejournal.kopertais4.or.id/mataraman/index.php/pikir/article/view/1483 